\title{
The Resilience of Aspiration: The Novelty of the Mystic Masseur
}

\author{
Julia Udofia, $\mathrm{PhD}$ \\ Department of English, University of Uyo, Uyo, Nigeria
}

\begin{abstract}
Recent criticism of V. S. Naipaul's The Mystic Masseur has tended to see this writer as presenting pessimistic visions of the Caribbean man and his environment. As an artistic mediator of his locale and historical experience, the argument seems to have been that the unrelieved gloom of his circumstances, the apparent absence of any controlling moral centre makes the only logical possible realistic portraiture absurd, depressing and hopeless. However, this paper challenges this stereotyped criticism and the objective is to show that Naipaul is an optimistic reformer rather than "a prophet of doom" .Being a literary research, the work is mainly library-based. First, V.S. Naipaul's The Mystic Masseur which is the primary text in this study has been rigorously examined and as many relevant critical works as could be found have been used to sharpen the focus of the arguments. In the end, it is found out that Naipaul is, indeed, an optimistic visionary whose vision aims to transform apparent hopelessness to hope and to point to the inevitable light at the end of the tunnel as demonstrated through the fortunes of the central character in the novel, and in the major technique - irony - employed by the writer in the work.
\end{abstract}

Key Words: Vision, Naipaul, optimistic, pessimistic, irony, satire, novelty, Caribbean

\section{Introduction}

V.S Naipaul has been accused of being a negative writer, "a prophet of doom", who holds out no hope of survival or of a better future for the Caribbean man and his environment. His characters are also seen as "failed" or "doomed". This is as a result of the critics' belief that Naipaul's characters embody or represent negative societal values. These characters are also seen as "failures" by these critics in the sense that they are non-achievers who fail to realise themselves materially. William Walsh's analysis is an example of this type of criticism. Referring to Naipaul's works, Walsh opines that, "when his (Naipaul's) characters are genuine, they are inevitably failures" (1973, p.81). Also, Bruce F. Macdonald opines that "V.S. Naipaul's Ganesh (of The Mystic Masseur) and Ralph of (The Mimic Men) ultimately fail because their symbolic actions are not supported by their own reality" (1977, p.254). Even Naipaul's technique - satire - is distrusted and seen more in the negative than in the positive light; as destructive rather than constructive. This accounts for The Daily Telegraph's accusation that Naipaul "looks down a long Oxford nose at the land of his birth" (1977, p.7). Reacting to Naipaul's The Mystic Masseur, R. M. Lacovia observes that, "after such powerful assertions of pessimism, A House stands out as an amazing act of redemption" (1971, p .122). Lacovia continues that, Naipaul resorts to satire because, "he has lost faith in the ability of the Caribbean" (1971, p.122). In the same vein, David Richards, writing in the Encyclopaedia of Literature and Criticism, (1991) suggests that
Naipaul be renamed "Nightfall" because of what he describes as Naipaul's "progressively" darkening vision" (13) which equally accounts for his being "expelled" by' George Lamming from those Lamming would regard as "West Indian Writers". This uncomplimentary reception of Naipaul's works, even resulting into hostility and antagonism to his person made William Walsh remark that even though Naipaul has the most distinguished reputation outside the West Indies, and is also the recipient of several awards, that he (Naipaul) "provokes distinct feelings of hostility among several of his fellow West Indians and not only literary ones" (1973, p.59).

In the light of these preliminary comments therefore, this paper is an attempt to re-evaluate earlier negative views on the vision of Naipaul, especially with regard to The Mystic Masseur (1971) and to suggest a new perspective which sees this writer as eventually seeking to present positive notions of the Caribbean man and the society. Thus, rather than view Naipaul as "pessimistic" as popular criticism is wont to, this paper seeks to see him as an optimistic visionary whose vision aims at transforming apparent hopelessness to hope, and to point to the inevitable light at the end of the tunnel. This is amply demonstrated through the fortunes of Ganesh, the central character in the novel, focusing on satire, the chief technique employed by Naipaul.

\section{Methodology}

The work is mainly library-based, and so, in addition to scrutinizing the primary text - The 
Mystic Masseur - other relevant critical materials as articles, reviews, interviews and critiques published on the primary text have been examined in a bid to not just appreciating the vision of this writer but also to viewing in the right perspective, his technique - irony.

\section{The Resilience of Aspiration and the Novelty of the Mystic Masseur}

In his travelogue, The Middle Passage (1969), Naipaul states that the novel must be concerned with the condition of men; must be a response to the here and now. He notes that here, the West Indian writers have failed, for most have so far only reflected and flattered the prejudices of their race or colour group because of the "insecure wish to be heroically portrayed" (p.74). Irony and satire which might help more, Naipaul regrets, are not acceptable, and no writer wishes to let down his group. Naipaul continues that, living in a "borrowed" culture, the West Indian more than most, needs writers to tell him who he is and where he stands and that to do this, the writer must possess the most exquisite gifts of irony, malice, subtlety and brutality. Naipaul however, adds that these gifts can grow only out of mature literature and that there can be advance towards this only when the writers cease to think of letting down their sides.

Naipaul possesses all the above gifts and he uses them abundantly in his novel, The Mystic Masseur (1971), which is examined in this paper. This novel, (The Mystic Masseur) charts the career of Ganesh Ransumair, the central character in the novel. Largely self-educated, Ganesh, the protagonist of the novel, is able to set up, initially as a masseur, and then, as a mystic. However, from a mystic masseur, Ganesh rises to become first, a member of the Legislative Council and then, a British representative at Lake Success. In the opening sentence of the novel, the boy-narrator defines Ganesh's career as a success story: "Later he was to be famous and honoured throughout the South Caribbean; he was to be a hero of the people and after that, a British representative at Lake Success"(p.7). As affirmation of this, at the beginning of the novel, the narrator's mother who takes him as a patient to see Pundit Ganesh tells him, "The day go come when you go be proud to tell people that you did know Ganesh". (p. 13).

It is, however, ironical that a series of failures launches Ganesh into international eminence. It is his "failure" as a teacher that turns him into a masseur, and his lack of success with massaging away ordinary pains that nudges him towards mysticism. What is in his favour, however, is his strange belief in his own genius, no matter how frequent his failures. This gift, he carries before him cupped in his hands. But as a person, Ganesh had very little to recommend him. If not dim, he was not really bright and never succeeded in becoming more than a mediocre student at school, where his father had scraped the money to send him, before his (Ganesh's father) untimely death.

Ganesh starts his career first, as a school teacher. But because he "informs" rather than "forms", he gets insulted for which reason he quits the job, though he remains undaunted. For sometime, Ganesh is undecided as to what to do before he eventually sets up as a masseur. However, he exploits to the fullest, the advantage of his little education. Throughout the novel, he reveals an alertness to the demands of both the world of the educated and of the uneducated. This is shown in the skill with which he manipulates people and events to his advantage in the novel. We first see Ganesh in action in the scene where he is getting married and where he out-foxes Ramlogan, his father-in-law. Another is in the episode where he disperses the deadly black cloud for the little boy and which also marks the turning point in his career. He repeatedly outwits Indarsingh who was a much more brilliant student at college. Also, he cleverly supplants Narayan as the leader of the Hindu community.

However, as Landeg White notes, it is difficult to discuss such alertness without giving the impression that as well as "being exceptionally clever, Ganesh is also exceptionally dishonest" (1975 p. 69). But Naipaul's ironic presentation of Ganesh, leaves the central issue of the novel whether or not Ganesh is a charlatan - open. Only an accumulation of circumstantial evidence suggests that he must be, but even here, Naipaul withholds condemnation and Ganesh emerges as a champion con-man in a world of small-time trickster with Naipaul seeming to say that, in a society largely given over to materialism, the mantle of the artist passes to the confidencetrickster and the double-edged ironic approach compels one to see him as both hero and Villain. Naipaul depicts a society in which the individual is forced to use subterfuge if he is to survive. For Ganesh and his fellow Trinidadians, there does not seem to be much freedom of a moral choice. Naipaul's portrayal of Trinidad as a society of predators and victims is, therefore, to be seen in this context. His characters are amoral, rather than immoral and emerge as the inevitable products of the society. Success is the reward of "trickery, vulgar materialism, self-delusion, or the values of the colonial monkey, game" (Derrick, 1977, p. 194). Naipaul makes the point that the Caribbean made it possible for Ganesh to emerge from rural obscurity. The change from con-man into a man worthy of confidence; the change which appears magical is the theme of this novel. Naipaul also implies that the lack of a hero or centre or focus in the West Indian society made possible the "farcical 
career" of Ganesh who blends "cunning, stupidity, ignorance and will-power into an extraordinary recipe for success" (p. 7).

In his book, The Middle Passage, Naipaul maintains that "slavery, the mixed population, the absence of national pride and the closed colonial system have to a remarkable degree recreated the attitudes of the Spanish picaroon world". (p.79). According to Naipaul, this is an ugly world in which you starve unless you steal and are beaten, unless you beat first. But he warns us that we must not condemn it out of hand for to do so would be to ignore its most important quality - tolerance, especially for every human activity. The Trinidadian, according to him is eccentric for there are no social conventions to which he must conform. The society in which he lives, Naipaul maintains is a fragmented, inorganic one in which the main concern is survival.

Naipaul continues: "Trinidad has always admired the "sharp character" who, like the sixteenth century picaroon of Spanish literature, survives and triumphs by his wit in a place where it is felt that all eminence is arrived at by crookedness". (1969, p. 78). However, the statement needs qualifying before applying it to The Mystic Masseur, for although Ganesh is a clever trickster hero, he is not unscrupulous enough to turn his back on all moral standards.

Ganesh is not even dishonest in any obvious sense. People are impressed by his holiness. The point is that he is perfectly attuned to his times. He is a hero because "the contradictions of his society are expressed and heightened in himself". (White, 1975 , p. 72). In this society, the "smart-man" is the hero, but the "smart man" is also a product of his society. Indignation at his activities is tempered by the recognition that he too is a victim of displacement. Naipaul insists on this point so well in The Middle Passage (1969) that his words are worth reproducing again. He prints a newspaper report that Valmond Jones, Secretary of the Sam Cooke Fan Club, has absconded with the ticket money for concerts for which Sam Cooke, despite the advertisements, was apparently never booked:

Three youths were talking about this affair one afternoon around a coconut-cart near the Savannah. The Indian said "I don't see how anybody could vex with the man. That is brains". "Is what my aunt say", one of the negro boys said. "She feel she pay the two dollars for the "intelligence". (p. 82).

Naipaul concludes that at once, analysis is made ridiculous, for here is a natural sophistication and tolerance which has been produced by the picaroon society: acceptance of every human activity and affection for every demonstration of wit and style which enables one to survive.

To achieve the ironic and objective tones, Naipaul in this novel as in his Miguel Street (1974) and The Mimic Men (1967) uses a narrator who breaks into the narrative from time-to-time and speaks in the first person "I". This is a literary technique and done within the framework of satire. The biographical nature of the narrator's account both distances and satirically inflates Ganesh's "early struggles". The narrator himself participates only twice in the action of the novel: once at the beginning as a young boy when he is taken as a patient to see Ganesh, and again at the end as a student at an English University. At the beginning of the novel, the narrator notes that Ganesh "was to be famous and honoured throughout the South Caribbean; he was to be a hero of the people and, after that, a British Representative at Lake Success" (p.7). In this opening chapter, and throughout the novel, the narrator appears to be taking Ganesh at his own and Trinidad's estimation. The formal, biographical treatment seems an understated acceptance of Ganesh's status in Trinidad and in the colonial office as "a public figure of great importance". Ganesh's own autobiography, The Years of Guilt (Ganesh Publishing Corn. Ltd., Port of Spain \$2.40) also provides a portentous background to which the narrator makes frequent reference.

The mode of presentation then, is clearly satirical, for, having told us that Ganesh achieved great success and became a "hero of the people", the narrator immediately goes on to show the society's preference for inefficiency and the quack: "... in those days people went by preference to the unqualified masseur or the quack dentist" (p.7). Ganesh's attempt to "cure" the narrator's foot at the beginning of the novel is itself a humorous demonstration of the quack masseur at work. The farcical incident and the popular attitude which make it possible, thus ironically counterpoint the narrator's observation that Ganesh "won the fame and fortune he deserved so well". Though Ganesh's chicanery is transparent in this episode, the narrator concludes that the masseur's mumbling of a Hindi couplet "showed, I am convinced about the incipient mystical leanings of the man" (p.12). The suddenly inflated language makes the observation sarcastic and accentuates the sort of mock-heroic terms of portrayal in the novel.

The farce of Ramlogan's naive ploys to secure a son-in-law is also a satirical comment on Ganesh's ominous note on the events leading up to his marriage: "I suppose, " Ganesh wrote in The Years of Guilt", I had always from the first day I stepped into Shri Ramlogan's shop, considered it as settled that I was going to marry his daughter ... It also seemed pre-ordained" (p.41). The narrator makes no comment on this and appears to take it at face value. It is really the highly comic examples of Ramlogan's intrigue that deflates Ganesh's solemn record of this experience. One soon realizes that the narrator is only pretending to take Ganesh's autobiography seriously, and its use as a formal, 
solemn background to the action of the novel, like the narrator's own formal biographical mode of portrayal, is really satirical. The narrator's caustic pretence is clearly evident when towards the end of the novel he pauses to consider Ganesh's rise from teacher to member of the Legislative Council:

Hence it might be well to pause awhile and consider the circumstances of Ganesh's rise, from teacher to masseur, from masseur to mystic from mystic to M.L.C...The autobiography shows that he believed strongly in predestination; and the circumstances which conspired to elevate him seem indeed to be providential. (p. 200).

The strike fiasco which shows the waning of Ganesh's influence and his inability to handle such an incident prompts the satirical equivocation of the narrator's final reference to providence and The Years of Guilt: "His whole attitude to the strike was so thoughtless that we can perhaps as he himself said later - see the hand of providence once more in his career". (p. 209).

Against the pretentious autobiography therefore, the narrator sets Ganesh's charlatanism and his final acceptance of a "glamorous mediocrity". That he was made "for something big" is Ganesh's belief early in the novel. Towards the end, he is sent by the British Government to "Lake Success" where he makes a "memorable" defence of British colonial rule". His "Lake of Success" seems a little more than a puddle. To the colonial office, he is an important political leader but that the narrator sets little store by this phase of Ganesh's life is suggested by the skipping of the narrative from 1950 to 1953 and by the final laconic dismissal: "In 1953 Trinidad learned that Ganesh Ramsumair had been made an M.B.E." (p. 214). It is a very minor decoration that he receives, but one which to Ganesh carries all the "panoply" of Empire and Royal Approval. That he takes the meaningless appendage so seriously suggests a naive delight in cheap humour.

It is through the narrator, then, that Naipaul illumines the short-comings of Ganesh and largely shapes the reader's response to the central figure in the novel. Early in the book, Naipaul makes these claims for the novel:

Nineteen forty-six was the turning-point of Ganesh's career; and, as if to underline the fact, in that year he published his autobiography, The Years of Guilt (Ganesh Publishing Co. Ltd., Port of Spain $\$ 2.40$ ). The book variously described as a spiritual thriller and a metaphysical whodunit, had a considerable success of esteem in Central America and the Caribbean. Ganesh, however, confessed that the autobiography was a mistake. So, in the very year of publication it was suppressed and the Ganesh Publishing Company itself wound up. The wider world has not learnt of Ganesh's early struggles and Trinidad resents this. I, myself believe that the history of Ganesh is, in a way, the history of our times, and there may be people who will welcome this imperfect account of the man Ganesh Ramsumair, masseur, mystic and since 1953, M.B.E. (p. 14).

The apparent pretentiousness of the claim is, of course, greatly modified by the mock historical tone of, and consequent irony directed towards the narrator. Yet "in a way", the novel is being advanced as a history of our times; and "in away", though not entirely the way the author intended, the claim is valid. In the first chapter of the book, the narrator tells us that our attention must be directed as much to Ganesh and his astonishing rise, as to the kind of world in which such a rise takes place.

The narrator's frequent references then to Ganesh's autobiography is clearly a technique which "serves to undermine Ganesh's attempts to conceal the fortuitousness of his career: It also tends however, to encourage us to see the whole career by hindsight as one of deliberate, calculated self-interest" (Edwards and Ramchand, 1971, p. xii). In this however, the author seems less than fair to his hero, for even with his election to the Legislative Council, Ganesh acts first, as a defender of the people, refusing to participate in the rituals of the British governors. He even champions a strike of sugar workers, on a vaguely Marxist platform. It is only when he is rough-handled by the crowd that his sympathies turn quite the other way. He begins to adopt the clothes and attitudes of the governors and from this time goes to cocktail parties at Government House and drinks lemonade. He also becomes an appointed, no longer an elected member, is awarded the M.B.E., and finally appears in England as G. Ramsay Muir.

Even Ganesh's “out-foxing” of Ramlogan does not strike the reader as exploitative. This point is driven home by the contrast between him and Indarsingh who now cruises in an Oxford Blazer. In fact, the presentation of the early years provides evidence that Ganesh has actually been of use to the villagers. His private ambition (to be a writer) leads naturally to public function: "and presently, peasants, crumpling their grimy felt hats in their hands came to ask him to write letters for them to the Governor or to read letters which the Government, curiously, had sent them". (p.75). As mystic, he had no fixed fees and accepted what the people could afford. He had compassion and flexibility: "He was a good listener. People poured out their souls to him and he didn't make them feel uncomfortable" (p. 134). However, Naipaul does not sentimentalise Ganesh. In the passage quoted above and throughout the summary of Ganesh's career, the author invites our doubts, for instance, the narrator says:

You never felt that he was a fake and you couldn't deny his literacy or learning - not with all those books. And he hadn't only book learning. He could talk on almost any subject. For instance, he had views about Hitler and knew how the war could 
be ended in two weeks. "One way", he used to say. "Only one way". And in fourteen days, even thirteen barn! - no more war. But he kept the way a secret. (p. 134).

We know that Ganesh's possession of "all those books" does not mean he is learned - only that his clients are impressed by appearances. We also know that Ganesh is talking nonsense about the war and that is why he keeps his solution a secret. It is equally doubtful whether Ganesh's copying out of stimulating passages into little note books will have any effect on his life particularly when he explains, "Is copying right enough, but it have a lot of thinking I doing at the same time." (p.79). The narrator continues:

And he could discuss religion sensibly well. He was no bigot. He took as much interest in Christianity and Islam as in Hinduism. In the shrine, the old bedroom, he had pictures of Mary and Jesus next to Krishna and Vishni, a crescent and star represented iconoclastic Islam. "All the same God", he said. Christians liked him, Muslims liked him, and Hindus, willing as ever to risk prayers to new gods didn't object. (p. 134).

Here, the irony and ridicule of Ganesh's charlatanism is unmistakable, for apart from images of other religions which Ganesh has in his shrine, he has also hung on his wall, the symbol of "iconoclastic Islam". Besides, it is Ganesh's "deliberate delivery" not the content, which gives weight to what he says and he is "concerned to put pompous people at their ease". The tone here too is ironic, leading us to see the corrupting elements that lie at the core of Ganesh's very virtues.

However, apart from Ganesh whom Naipaul satirises for his second-rate success, Naipaul also satirises the fossilized Indian community as well as the larger static Trinidad society which he sees as religion-and-taboo-ridden, where Ganesh's predominantly fortuitous drift to eminence takes place. The satire also attacks quackery (dentists and masseurs), knavery (bribery and fraud in public life), incompetence (the educational system) and a lack of standards at all levels in the society. As in his The Suffrage of Elvira (1969) and A House for $M r$. Biswas, (1969), Naipaul satirises the educational system which with its accent on things irrelevant to the local situation, produces neocolonial "mimic men". And so, governing the world of Ganesh is the trap of a colonial: "the awe of the illiterate at education and the power of the printed word or the presence of the "cultured" person; and the aspirations of half-educated men in a formless society towards the pasteboard images of the B.A. degree, the refined voice, or the name on the title-page of a book" (Edwards and Ramchand, 1971, p. vii). The "mathematical approach" to learning and the awe of the illiterate at the written word are also turned to great comic effect in this novel. Early in the novel, the boy-patient's amazement at the number of books in Ganesh's consulting room and rural home university leads to this exchange between the masseur and his wife:

"Leela, Ganesh said, "the boy want to know how much book it have here". "Let me see", Leela said, .. She started to count off the fingers of her left hand. "Four hundred Everyman, two hundred Penguin...

"They is all yours, pundit?" I asked. "Is my only vice", Ganesh said... I don't smoke. 1 don't drink. But I must have my books. "... How much book I buy last week, Leela?". "Only three man" she said. "But they was big books, big big books. Six to seven inches altogether". "Seven inches", Ganesh said". (p. 11).

With the possession of books comes the respect of others; one is a pundit, a wise man, and this is an assertion of the individual's stature. The person transcends the squalid hamlet and assumes an identity in the minds of others: "I often thought with a good deal of puzzled interest about the little man locked away with all those fifteen hundred books in the hot and dull village of Fuente Grove" (p. 13).

The arrival by van of the three hundred volumes of the Everyman Library and his plan to fit onto his wall seventy-seven feet of bookshelving are comic, so are his notebooks which are to contain the findings of his researches which, started in "a fine sloping hand", but petering out in "a hasty, tired squiggle" are never filled beyond the first few pages. Worse still, a warped aestheticism begins to flourish in Fuente Grove for Ganesh "began to acquire some sensitivity to type-faces. Although he owned nearly every Penguin that had been issued, he disliked them as books because they were mostly printed in Times, and he told Beharry that it looked cheap, "like a paper". (p. 83).

Naipaul also satirises politics as a charade. As a person, Naipaul is not interested in politics. He confesses: "I am never disturbed by national or international issues. I do not sign petitions. I do not vote. I do not march". (Hamner, 1977, p.12). Naipaul views politics as an opportunity for selfgain. Equally satirised is the society and the characters for having no fixed standards of conduct and for their comic misunderstanding of the benefits of civilization. Naipaul sees his countrymen as involved in a hopeless conflict between civilization and barbarism which he believes is as a result of the Island's want of a historical past. As R.H. Lee remarks, there is an abundance of double- edged satire in this description of the dinner party given by the governor to the newly-elected members of the Legislative Council . Ganesh is hesitant about the correct use of cutlery, so are the other guests:

The members looked at the waiters who looked away quickly. Then the members looked at each other .... Soup came, "Meat?" Ganesh asked. The waiter nodded. "Take it away", Ganesh said with quick disgust. The man in jodhpurs said, "You was wrongthere. You shoulda toy with the soup..... Is 
what the book say". The man in jodhpurs sighed wearily. "Is a funny thing, but I ain't so hungry today... The Christian Indian placed his daughter on his left knee, and, ignoring the others, dipped a spoon in his soup. He tasted it with his tongue for warmth and said "Aah". The girl opened her mouth to receive the soup." One for you", the Christian said. He took a spoonful himself. "And one for me". The other members saw. They became restless and ate. (p. 203).

Naipaul in this episode succeeds in giving the right balance of irony to the ignorance of the members, and the absurdity of colonial dining ritual. He depicts an imaginary confrontation between the most unsophisticated members of the Creole and Indian societies and the hypercivilized governor's wife. Many of the things Naipaul finds ridiculous are paraded here: the bad grammar, lack of taste or social grace, complete unawareness and the struggle to be white.

The scene, however, has been much criticised on the grounds that Naipaul, secure in the achievement of having dined at Oxford, thinks it funny to ridicule West Indian table manners. However, if this were the point, it would, indeed, be a very cheap triumph. But as White points out, Naipaul's purpose is to complete his picture of the society of which Ganesh is the hero, and to show that what has been true of the peasants is true also of the new elite. Such are the varieties of displacement that it is impossible for the new legislators to sit down at table together without the most elementary problems arising - problems of culture and principle, and only superficially of table manners. Ganesh himself, for instance, accustomed to eating with his fingers, consults a friend about knives and forks, and turns up wearing dhoti, koortah and turban. Other guests wear dinner jackets, jodhpurs, khaki suits and sun helmet, or ("adhering for the moment to his preelection principle's) shorts and an open shirt. Mr. Primrose, the blackest negro, whose blackness Naipaul makes a special point of, comes in a blue suit with yellow gloves and monocles which fall inside his soup. He brings his second wife, a teetotaller, by contrast with the Indian Christian who, never having been married brings his four year old daughter - with whom he shares, the meat soup that Ganesh, the Hindu, rejects in disgust. The hostess is the governor's wife, who is equally ironically presented as she presides with assurance and determination over an occasion unfamiliar to everyone except herself. This episode is significant also in the sense that it mocks the pseudo-European grotesqueries of local leaders of African and Indian origin alike. What Naipaul seems to be implying here is that creolization in these Islands has proceeded not as the growth of a civilization indigenous to the area but as a superficial mimicry of models derived from what is unthinkingly regarded as a superior European culture.

\section{Conclusion}

From the foregoing, Naipaul's unfavourable critical reception comes as no surprise, for as David Bates remarks, the "wit, irony and sophistication" found in his (Naipaul's) early books were mistaken for "irresponsible satire" (p. 159). Similarly, speaking of Naipaul's early novels (which include The Mystic Masseur), George Lamming decries their satire, seeing it as an inadequate refuge from hard experience - laughter as a cowardly defence mechanism. Lamming writes: "His books can't move beyond a castrated satire; and although satire may be a useful element in fiction, no important work ... can rest safely on satire alone.... Satire, like the charge of Philistinism, is for me, nothing more than a refuge. And it is too small a refuge for a writer who wishes to be taken seriously" (p. 78). Here, there is the assertion that mere irony is irrelevant to the West Indian society at this stage. Thus, satire, it is argued, is a means of running away from the sordid truth through seeking recourse in laughter.

However, the point Lamming misses in this argument is the offensive power of satire; its usefulness in confronting the very problems Naipaul is accused of avoiding. Lamming also fails to note that Naipaul's humour, irony and satire provide indispensable means for keeping his personal involvement as a man from eroding the detachment which is essential to him as an artist.

Still commenting on Naipaul's incisive humour, Victor Ramraj notes that Naipaul has been described as "a sardonic satirist, writer of farce, pure and simple" (p. 128). Again, what this critic misses as Naipaul himself points out is that the comic and satirical forms reveal greater concern for suffering humanity than compassion. That Ganesh is treated so comically seems to conceal his writer's seriousness of purpose. One should not be misled by Naipaul's genial tones to overestimate his admiration for Ganesh. As David Ormerod remarks, Naipaul has consciously invoked comedy in order to say something deeply and seriously felt about a social predicament. As Naipaul observes, "True satire grows out of the largest vision...that all embracing Christlike vision.... Today sights are set lower; satire is compounded of anger and fear, which exalt what they seek to diminish". (1969 p.129).

So, it becomes difficult to see how Ganesh is a "failure" as Bruce F. Macdonald asserts. From a struggling masseur with basic education, but through dint of hard work and application of his knowledge, Ganesh rises to become a distinguished statesman. Even though he changes into a funny neo-colonial "mimic man" which Naipaul satirises, Ganesh achieves a rise in status and whatever faults he has are blamed more on the society that nurtured him. Ganesh prospers and through him Fuente Grove, a formerly unknown hamlet prospers too. In fact, Anthony Boxill makes the suggestion that Leela's 
sterility may be taken to reflect and emphasize the sterility of Fuente Grove . Ganesh constructs a miniature India in Fuente Grove which now becomes a tourist centre. It is Ganesh who brings electricity, pipe-borne water and other basic amenities to Fuente Grove. Through his efforts too, the road to Fuente Grove is resurfaced. In fact, early in the novel when Ganesh had completed his house, the first of its kind in Fuente Grove with all its modern installations, Naipaul had remarked that, that in itself was a considerable achievement to a Trinidad West Indian, a point he elaborates on and sustains in his A House for Mr. Biswas (1969). Significantly, Ganesh's name is derived from "Ganesa", the elephant god which is the Hindu "god of success".

Again, it is equally difficult to see Naipaul as "pessimistic" as R.M. Lacovia asserts because, like all satirists, Naipaul is concerned with reform. Beneath Naipaul's comedy is a strong sense of the tragic; a sense that the laughter is there to cover up the cry. Ganesh's story is a condemnation of the forces which have created the society in which his success takes place.

In The Middle Passage (1969), Naipaul writes that nationalism is the only revitalising force in the West Indies and that he believes the West Indian needs writers to tell him who he is and where he stands (p.70). This is what Naipaul does in this novel, The Mystic Masseur: holding up the society's weaknesses to ridicule in the hope of improving it so that the overall impact conveyed to the reader is the same as that made by the likes of Swift, Pope and Dryden - discontent and the need for change - rather than of pessimism. And so, in this sense, no matter how remote it may seem to critics, there is the implication of an unrealized system of values; an ideal of order for which reason we refer to Naipaul as an optimistic reformer.

\section{References}

Boxill, A. (1975). V.S. Naipaul's starting point. The Journal of Commonwealth Literature, X,(1), 36-42.

Edwards, P. \& Kenneth Ramchand (1971). Introduction to The mystic masseur. London: Heinemann.

Hamner, R. (1977). Naipaul's perspectives. In Robert Hamner (Ed.), Critical perspectives on V.S. Naipaul (pp. 67-77). Washington D.C.: Three Continents Press.

Lacovia, R.M. (1971). Caribbean literature in English: 19491970. In S.O. (Ed.), Modern black literature (pp.19-21). Buffalo: Black Academy Press, Inc.

Lee, R. H. (1977). The novels of V.S. Naipaul". In Robert Hamner (Ed.), Critical perspectives on V.S. Naipaul (pp.51-64). Washington D.C: Three Continents Press.

Naipaul, V.S. (1971). The mystic masseur. London: Heinemann.

- (1969). The middle passage. London: Penguin Books.

- (1974). Miguel street. London: Heinemann.

- (1967).The mimic men. London: Andre Deutsch.

- (1969).The suffrage of Elvira. London: Penguin Books, Ltd.

- (1969). A house for Mr. Biswas. London: Penguin Books.

Ormerod, D. (1977). In a derelict land: The novels of V.S. Naipaul. In Robert Hamner (Ed.), Critical perspectives on V.S. Naipaul (pp.25-37). Washington D.C.: Three Continents Press.

Ramraj, V. (1977). The all-embracing Christlike vision: Tone and attitude in The mimic men. In Robert Hamner (Ed.), Critical perspectives on V.S. NaipauI (pp.71-83). Washington D.C.: Three Continents Press.

Richard, D. (1991). West Indian literature. In Martin Coyle and Co. (Eds.), Encyclopaedia of literature and criticism (pp.66-78). London: Routledge.

Rohlehr, G . (1977). The ironic approach: The novels of V.S. Naipaul. In Robert Hamner (Ed.), Critical perspectives on V.S. Naipaul (pp.81-92). Washington D.C.: Three Continents Press.

Walsh, W. (1973). V.S Naipaul. Edinburgh: Oliver and Boyd.

- (1973). Commonwealth literature. London: Oxford University Press.

White, L (1975). Trinidad full of crazy people. In Landeg White (Ed.), V.S. Naipaul: A critical introduction ( pp.90102). London: Macmillan. 